\title{
Studying to use volcanic ashes and felsic volcanic rocks in Vietnam teritory as the treatment materials for environment pollution - preliminary results
}

\author{
Giang Nguyen Khac, Dung Le Tien, Van Anh Pham Thi, Nui Pham Xuan, Ban To Xuan \\ University of Mining and Geology, \\ 18 Pho Vien, Bac Tu Liem, Hanoi, Vietnam.
}

\begin{abstract}
The felsic volcanic rocks and tuff aged from Late Mesozoic to Kainozoic occur in many places in Viet Nam Territory, such as Tu Le area (in Northwest Region), Binh Gia area, Binh Lieu area (Northest Reigion), Nha Trang area, Dalat area (Central Region). The mafic volcanic ashes aged from Late Neogen to Quarternary distribute in central part of Vietnam such ash Con Co Island, Van Hoa High land. The samples of the tuff rock of Don Duong Stratum collected from field trip in $\mathrm{Da}$ Lat area have been treated (burned) at $650^{\circ} \mathrm{C}, 750^{\circ} \mathrm{C}, 900^{\circ} \mathrm{C}$. The experimental results show that these materials, after treatment (heating in funace at the temperature $650^{\circ} \mathrm{C}, 750^{\circ} \mathrm{C}$ and $900^{\circ} \mathrm{C}$ ) expressed absortion capacity up to $90 \%$ of selected organic matters (MO, MD) and heavy $\left.\mathrm{Metal}_{(\mathrm{Pb}}{ }^{2+}\right)$ in the testing solutions. Among them, the sample heating at $900 \mathrm{oC}$ is the best material for $\mathrm{Pb}^{2+}$ absorption. The preliminary results show that the volcalnic felsic rocks and volcanic ashes in Viet Nam, after suitable treatments, can be used as an enviroment treatment materials.
\end{abstract}

\section{Key words: Environment, perlit, tuff, Vietnam}

\section{INTRODUCTION}

Felsic volcanic rocks and volcanic ash formation consist of microscopic minerals and glass volcanic rock types in amorphous state, which contain a relatively high amount of water, usually formed by effusive and eruption processes. The geological, composition study of the geology, material composition and origin of felsic volcanic rocks in the world is often accompanied by studies on the classification of volcanic rocks. Classification and nomenclature of volcanic rocks in general and volcanic clasts in particular by the IUGS Sub-Committee [1] on Geological Nomenclature as follows:

Volcanic ash is the term for volcanic eruptions containing crushed rocks pieces formed during volcanic eruptions with a diameter of less than $2 \mathrm{~mm}$. This is also used in a broader sense to refer to all erupted products (more commonly referred to as tephra or pyroclast volcanic material), including those larger than $2 \mathrm{~mm}$ in size.

The mineral composition of the volcanic ash depends on the source of the magma. Basalt effusions usually have dark ash with about $45-55 \%$ silicon oxide and are rich in
$\mathrm{Fe}$ and $\mathrm{Mg}$. Felsic volcanic rocks (eg. rhyolite) often produce light colored ash with high silicon oxide content (> 69\%). Ash dust from intermediate magma has a silicon oxide content of around 55-69\%. In the ashes usually contain cations $\mathrm{Na}^{+}, \mathrm{K}^{+}, \mathrm{Ca}^{2+}, \mathrm{Mg}^{2+} \ldots$ and the $\mathrm{Cl}^{-}, \mathrm{F}^{-}, \mathrm{SO}_{4}{ }^{2-}$. The volcanic gases are water vapor $\left(\mathrm{H}_{2} \mathrm{O}\right)$, $\mathrm{CO}_{2}, \mathrm{SO}_{2}, \mathrm{H}_{2} \mathrm{~S}, \mathrm{CO}$ and $\mathrm{HCl}$. When lava is erupted onto the ground, these gases partially drain out of the environment, or trapped in rocks and glass as liquid-gas inclusions.

Felsic volcanic rocks and pyroclasts are formed by erupting or effusive activities. The main materials that make up the felsic eruptions are the microcryts and phenocrysts of quartz, feldspar and glass. Material sources of volcanic rocks include pebbles, boulders, dust ash with the composition same as lava. Volcanic ash layers are distributed or are the bottom parts of real volcanic layers. The subject of investigation, research of this project is the ashes, volcanic ash (tuff ash), composed of particles of size $<2 \mathrm{~mm}$. Tuff rocks have a very diverse composition, roughly equivalent to the real volcanic rocks. To classify the tuffs often add the names of the corresponding volcanic rocks. For example, the term basalt ash tuff is fully understood as a volcanic

Corresponding Author: Giang Nguyen Khac, University of Mining and Geology, Hanoi, Vietnam 
clast rock, with very fine particle size $(<2 \mathrm{~mm})$ which accounts for over $75 \%$ of rock mass, chemical composition is equivalent or close to basalt.

The natural volcanic rocks as described above contain many materials in the glass state, such as volcanic ash tuff, volcanic felsite, which have many properties that can be used to produce materials in many different directions:

- As filter materials: clean water for drinking, sewage treatment, beverage filter, use for food processing [2];

- Supporting materials for plant care: use in tree nursing, nursery, soil porous improvement, plant and flower nutrition as well as application for clean vegetables, vegetable cultivation by hydroponic method [3];

- Other using sectors: Rich natural glass products are also used as materials for heat-insulating products, fireproofing, heat-insulating concrete, and porous concrete [2-6]. Perlite for gas separation and air separation for gas separation towers.

These materials have been used in many countries of the world. In Vietnam, raw materials processed from volcanic rock such as perlite and basalt have started to be used. The research on the application of natural rock materials in the field of production of environmental treatment materials and fertilizer derivatives for plants in Vietnam is very limited, only some researches related to the use of clay bentonite and diatomite as filter material. The use of highly active basalt as an additive for roller compacted concrete has been conducted in some hydropower works such as Plei Krong (Kon Tum), Ban Ve (Nghe An). Rotary kiln cement plants use basalt as an active adder to produce PPC cement [7].

However, the use of volcanic ash (mafic) and perlite (felsic) rocks for the production of environmental treatment materials as well as water-retaining materials (fertilizer derivatives) for crops is almost not to be research interests and applications. Most recently Nguyen and Doan [8] in the work "Initial research results on the ability to use weathering basalt on the islands of Ly Son and Con Co in the production of heavy metal adsorption in water pollution treatment" presented some results of research on environmental geochemistry and the ability to use weathering basalt in Con Co and Ly Son islands to serve the sustainable development of the sea and islands of Vietnam.

Up to the present time, all of these materials used in environmental and agricultural sectors are almost still imported from overseas such as Taiwan, Korea. Finding the source of raw materials for domestic production will have significant socio-economic implications.
To clarify the use of volcanic ash and volcanic ash, the authors of the University of Mining and Geology has been allowed by the Ministry of Education and Training to conduct research on the use of felsic volcanic felsic eruption and volcanic ash in the environment (Project B2016-MDA-16DT). The following is the preliminary research results of the authors.

\section{AN OVERVIEW OF THE DISTRIBUTION OF FELSIC ERUPTIONS AND VOLCANIC ASH IN VIETNAM}

In the Vietnamese territory, volcanic rocks as well as magmatic rocks in general have been studied, which have been mapped in detail on small to medium scale geological maps. According to the published geological data [11-15], the geological complexes of the volcanic rocks are distributed in many age ranges, especially the late Mesozoic and Cenozoic volcanic rocks. On maps, they are divided into facies, subordinates according to the principle of mapping the rock facies. The object of concern is the perlite and glass-rich felsic volcanics in the late Mesozoic to Cenozoic periods as well as tuff rocks and volcanic ash in the Cenozoic basalt effusions.

\section{Modeling Late Mesozoic and Cenozoic felsic rocks}

Late Mesozoic-Cenozoic felsic rocks are distributed in Tu Le (Yen Bai), Lang Son, Tan Mai (Quang Ninh), Muong Hinh (Thanh Hoa), Deo Ngang (Quang Binh), Mo Ray (Kon Tum), Mang Giang (Gia Lai), coastal areas from Quy Nhon to Nha Trang, and Da Lat area. The mass of volcanic rocks predominates, in which many places, have described perlitic rocks, nonphenocryst felsic rocks $[11,13]$. The above rocks are mainly located at the top of the lava flows. They are capable of being used in the environment as perlite.

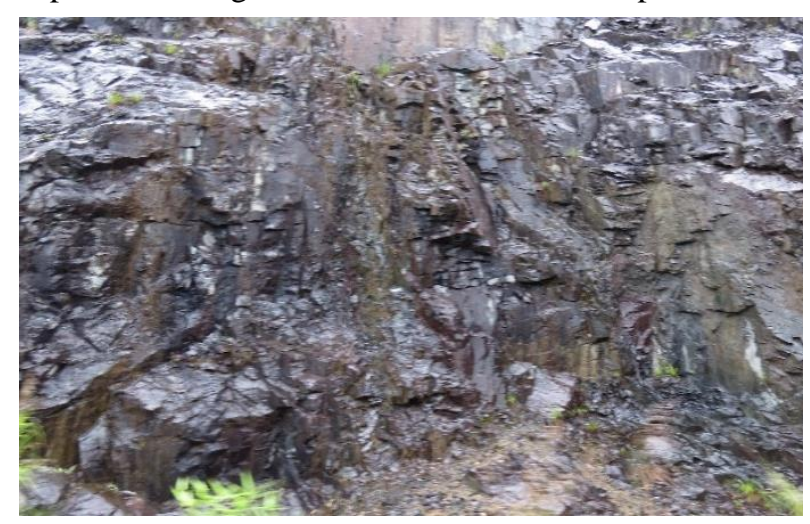

Fig 1 Outcrop of tuff rock of Don Duong stratum (PY19) in Da Lat area of Lam Dong province (Lâm Đồng) 
In the study work on geology of Son La hydropower work, on the profile of Nam Chien stream, the description of Le (2001) [9] confirmed the presence of colored patches rocks with thickness of tens meters are partially weathered into kaolinite.

The description of Do and Nguyen [10] showed that the volcanic rocks of the Song Hien stratum in Binh Gia district (Lang Son province) have a recrystallized glass ground up to $75-80 \%$. These rocks may have potential for use in environmental and agricultural purposes as described above.

\section{Basalt and tuf ash in the Cenozoic basalt eruption}

Basalt Cenozoic volcanic are widely distributed in Phu Quy (Nghe An), Quang Tri, Van Hoa plateau (Phu Yen) and Central Highlands (Gia Lai, Dak Nong, Dak Lak). They form layers with thickness ranging from a few meters to several hundred meters above the preCenozoic geologic formations. According to published documents, the largest thickness of the basalt at Pleiku is to about $550 \mathrm{~m}$.

In the distribution fields of the Cenozoic basalt volcanics, in addition to the real effusions, there are significant amounts of volcanic clastic rocks. According to the classification of the IUGS, they include tuff agglomerate, tuff clasts, glass tuff, debris basalt tuff. Notably, the presence of volcanic ash tuffs. These volcanic ash, due to their formation conditions, often have large amounts of amorphous silicon. Facilitate the formation of technological characteristics that can be used in the field of environment and agriculture.

The glass-rich volcanic rocks have been studied and recorded the widespread distribution in the territory of Vietnam. However, the studying works on their application in life are few. A number of studies have been conducted in the field of science and technology, published in articles in the Journal of Geology. However, most of these works are only interested in the active index of basalt material (fresh and sub-weathered rocks) and weathered soil layer from them. Completely absent from research works and production of materials from perlite and felsitic glass volcanics.

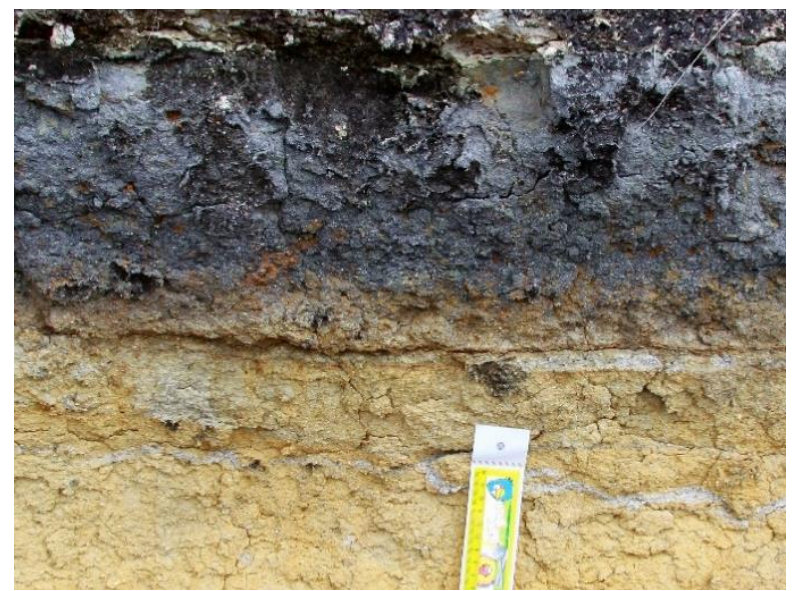

Fig 2 Outcrop of volcanic ash (dark color) of Dai Nga stratum in Kbang area (Gia Lai).

Mineralogical AND CHEMICAL COMPOSITION OF TYPICAL FELSIC VOLCANIC ROCKS AND VOLCANIC ASH

\section{Mineralogical composition}

The results of the study published by many authors (e.g. Le and Pham [14], Nguyen and Doan [8], Tran et al. [17], Do and Le [15], Dao and Huynh [13], Bui et al. [16]) and the results of the analysis of the authors showed that in the felsic volcanic rock of Don Duong stratum has the major mineralogical components include: Phenocrysts $(15-17 \%)$ include plagioclase, potassium feldspar, quartz, biotite and less hornblende. Groundmass includes micrograins of feldspar, quartz, few of sericite, chlorite, and epidote. Minor (accessory) minerals are magnetite, hematite, ilmenite, pyrrhotine, apatite, and zircon.

The mineral composition of the Cenozoic basalt rocks has been studied by the authors of geological maps 1 : 200,000 and 1.50.000 initially: in which rocks the main rock-forming minerals in most of the basalt rocks in the Central Highlands include: olivine (Ol), orthopyroxene (Opx), clinopyroxene (Cpx), plagioclase (Pl); secondary minerals: amphibole $(\mathrm{Am})$, biotite $(\mathrm{Bi})$, potassium feldspar (Fsp); accessory minerals: magnetite (Mt), ilmenite (Ilm), spinel (Spl).

\section{Chemical composition}

The chemical composition of typical felsic volcanic rocks (Tu Le Stratum in the North and Don Duong Stratum in the South) are shown in Fig 1 and Table 1. 
Table 1 Chemical composition of typical Mesozoic-Cenozoic felsic volcanic rocks in Viet Nam (\%)

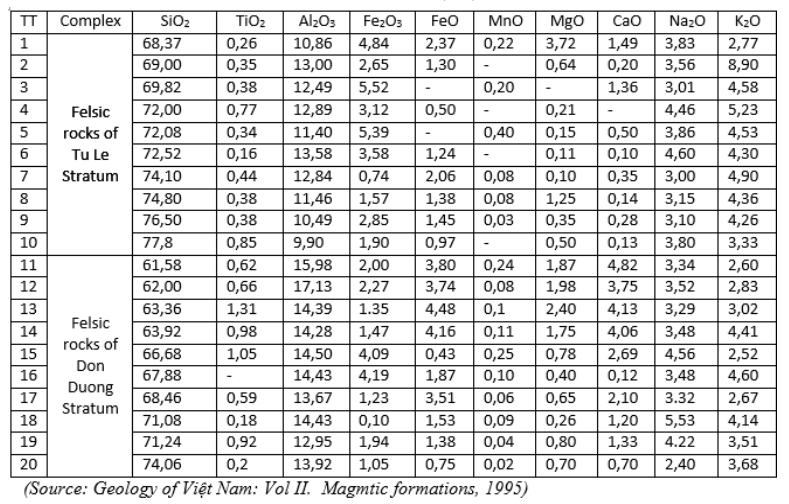

The chemical composition of the Cenozoic basalt rocks is presented in Table 2 .

Table 2 Chemical composition of major components of Cenozoic basalt rocks in Vietnam (\%).

\begin{tabular}{|c|l|l|l|l|l|l|l|l|l|l|l|}
\hline$\pi$ & Rock Name & $\mathrm{SiO}_{2}$ & $\mathrm{TiO}_{2}$ & $\mathrm{Al}_{2} \mathrm{O}_{3}$ & $\mathrm{Fe}_{2} \mathrm{O}_{3}$ & $\mathrm{FeO}$ & $\mathrm{MnO}$ & $\mathrm{MgO}$ & $\mathrm{CaO}$ & $\mathrm{Na}_{2} \mathrm{O}$ & $\mathrm{K}_{2} \mathrm{O}$ \\
\hline 1 & $\begin{array}{l}\text { Rich Aluminum } \\
\text { Basalt }\end{array}$ & 48,98 & 1,83 & 17,06 & 4,25 & 5,72 & 0,15 & 3,20 & 8,01 & 3,05 & 1,76 \\
\hline 2 & $\begin{array}{l}\text { Andesite } \\
\text { Basalt }\end{array}$ & 53,19 & 1,40 & 15,03 & 3,62 & 6,75 & 0,64 & 5,45 & 7,80 & 2,64 & 0,69 \\
\hline 3 & Tholeite Basalt & 49,34 & 1,83 & 14,19 & 5,01 & 6,62 & 0,19 & 6,82 & 7,74 & 2,76 & 1,24 \\
\hline 4 & Dolerite Basalt & 50,37 & 1,68 & 14,14 & 4,11 & 6,06 & 0,14 & 6,72 & 8,35 & 2,61 & 0,82 \\
\hline 5 & $\begin{array}{l}\text { Alkaline olivine } \\
\text { Basalt }\end{array}$ & 49,79 & 2,13 & 14,13 & 4,72 & 7,33 & 0,21 & 8,33 & 8,52 & 3,07 & 1,43 \\
\hline 6 & Basaltite & 43,26 & 2,58 & 14,33 & 5,54 & 6,76 & 0,15 & 8,60 & 8,68 & 3,01 & 1,97 \\
\hline 7 & Trachite Basalt & 52,99 & 1,05 & 15,80 & 5,23 & 4,36 & 0,15 & 4,50 & 3,66 & 4,83 & 2,84 \\
\hline 8 & $\begin{array}{l}\text { Phonolite } \\
\text { Basalt }\end{array}$ & 56,60 & 0,26 & 18,74 & 3,19 & 2,24 & 0,11 & 0,30 & 2,40 & 7,00 & 6,00 \\
\hline
\end{tabular}

PRELIMINARY RESEARCH RESULTS ON THE CAPACITY OF HEAVY METAL ADSORPTION OF FELSIC

VOLCANIC ROCKS AND VOLCANIC ASH

In order to evaluate the heavy metal adsorption capacity of the felsic volcanic rocks, we selected the typical samples from the tuffs of the Don Duong formation in the Da Lat area (Sample PY19) (Fig 1). The samples were milled to a particle size of $<0.001 \mathrm{~mm}$ and placed in the porcelain cup and covered with the lid, then placed in the furnace. Perform heating 3 times at $650^{\circ} \mathrm{C}, 750^{\circ} \mathrm{C}$, $900^{\circ} \mathrm{C}$ for 3 hours. After the heating process has finished, return the sample to its normal temperature and take out the cup.

\section{Characteristic analysis of structure and properties of PY19 material}

Determine the structure of PY19 by X-ray diffraction (XRD). Sample material was spotted with X'Pert PRO at the Institute of Chemistry-Materials, Military Science and Technology Institute. The result is that the XRD spectrum has characteristic peaks of the material from which it is compared to the standard spectrum.

As can be seen in Fig 3a,b, PY19 after heating at $900^{\circ} \mathrm{C}$ retains the same strong strength peaks as PY19 at the $2 \theta$ (theta) angles of $21^{\circ}, 27^{\circ}, 50^{\circ}$ and four weak strength peak at $2 \theta$ (theta) angles of $21^{\circ} .24,5^{\circ} ; 31^{\circ}$ and $68^{\circ}$. These are the typical peaks of the material. The most obvious difference of PY19 after heating is increased peak height. Specifically, the primary material had a peak height of more than 1600 and the material after baking peaked at 3600 . The change in peak height after heating due to the material after heating liberated the bonding water, leaded to expansion of material and thereby, increasing the absorption capacity of the material. In order to know the morphology, the structure of the material, we continue to carry out SEM in the next experiment.

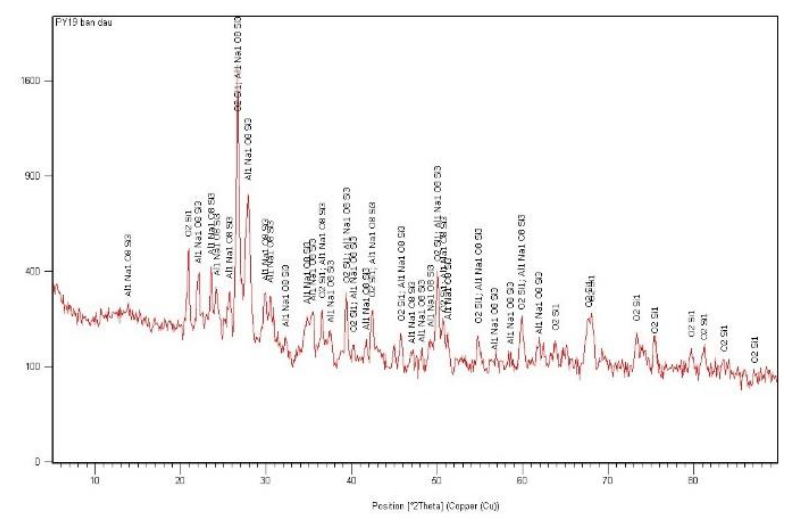

(a)- Primary material (before heating)

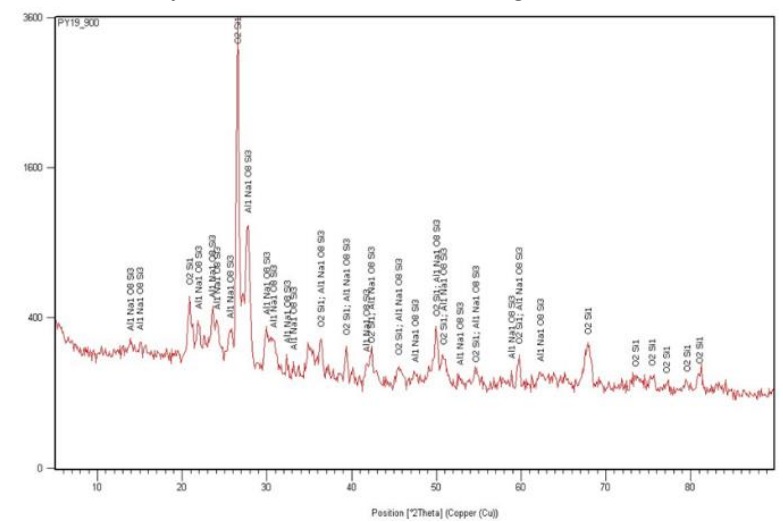

(b)- After heating at $900^{\circ} \mathrm{C}$

Fig 3 XRD analytical results of sample PY19

Determination of surface morphology of PY19 by scanning electron microscope (SEM). Material samples were taken by HITACHI S - 4800 at the Institute of Chemistry, Vietnamese Academy of Science and Technology. 
The result is an SEM image, which indicates the external morphology and particle size of the material.
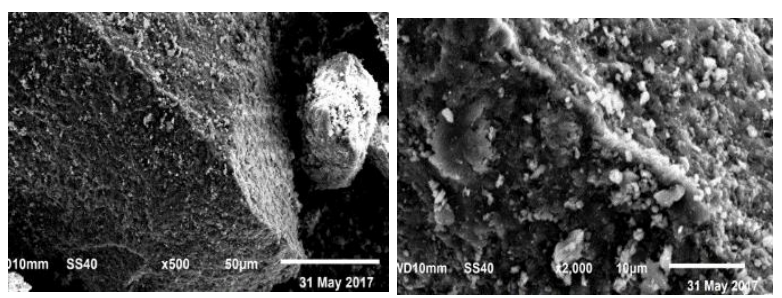

(a)- PY19 Primary material

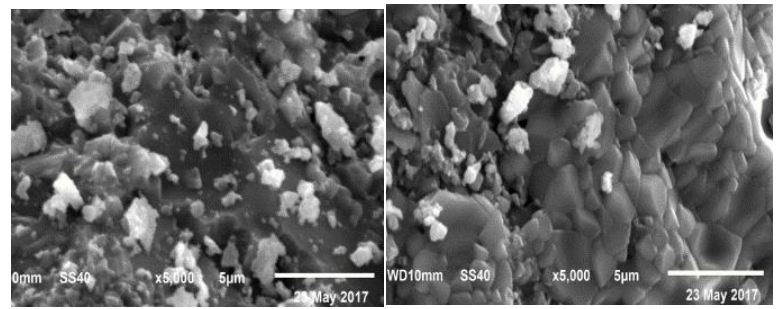

(b)- PY19 material after heating at $900^{\circ} \mathrm{C}$

Fig 4 Scanning electron microscope of material from sample PY19

Observation in Fig 4 shows that the initial PY19 material (Fig 4a) is in cubic form, with crystal structure, on the surface being the different composition of the material. After heating at $900^{\circ} \mathrm{C}$ (Fig 4b), the material is no longer in the form of a cube, but is spread out because the released water molecules produce more porous material with crystalline phases clearly visible when heated in the high temperature and composition are not changed.

\section{Adsorption capacity of $\mathrm{MB}, \mathrm{MO}, \mathrm{Pb}^{2+}$ from primary} PY19 and denaturation (modified) materials. - Select the concentration of adsorbent solution of 10 $\mathrm{mg} / \mathrm{l}$ to examine the primary PY19 material. - The experiment is conducted as follows:

Step 1: Accurately weigh $0.01 \mathrm{~g}$ of material and put into a $100 \mathrm{ml}$ glass; Step 2: Take $50 \mathrm{ml}$ of $\mathrm{Pb}^{2+}$ solution, $\mathrm{MB}$, MO in each cup; Step 3: Stirring the mixture for 2 hours then filtering the solution and conduct measuring atomic absorption spectrometry for $\mathrm{Pb}^{2+}$ samples and photometry measuring for $\mathrm{MB}$, $\mathrm{MO}$ samples to determine the concentration after treatment.

(1) Examination of $\mathrm{Pb}^{2+}$ adsorption capacity of modified PY19 material. According to the Vietnamese Standards (QCVN-40-National Technical Regulation on Industrial Wastewater), the maximum permission limit of $\mathrm{Pb}^{2+}$ is $0.5 \mathrm{mg} / \mathrm{l}$ (for wastewater discharged into the nondomestic use purpose sources), so in this study, the selected initial $\mathrm{Pb}^{2+}$ concentration was $20 \mathrm{mg} / \mathrm{l}$ (40 times higher than that of $\mathrm{QCVN}$ 40) to investigate $\mathrm{Pb}^{2+}$ absorption capacity of the material. Experimental conditions: Treatment of $\mathrm{Pb}^{2+}$ at a concentration of 20 $\mathrm{mg} / \mathrm{l}$ at $25^{\circ} \mathrm{C}$, normal light; $\mathrm{pH}=6.01$. Experiment with different time intervals: 30, 60, 120, 240, 480 minutes. (2) Investigate the effect of $\mathrm{pH}$ on the $\mathrm{Pb}^{2+}$ adsorption capacity. Experimental conditions: Treatment of $\mathrm{Pb}^{2+}$ at a concentration of $20 \mathrm{mg} / \mathrm{l}$ at $25^{\circ} \mathrm{C}$, normal light; $\mathrm{pH}=$ 6.01. Select the optimal time in Experiment 1 with different $\mathrm{pH}$ ranges: $2,4,5,6,7,9$. (3) Investigate the effect of concentration on adsorption capacity of $\mathrm{Pb}^{2+}$. Experimental conditions: Treatment of $\mathrm{Pb}^{2+}$ at concentrations of $10,20,50,75,100,200 \mathrm{mg} / \mathrm{l}$ to describe linear adsorption until saturated, at $25^{\circ} \mathrm{C}, \mathrm{pH}=$ 6.01. Select optimal time in experiment $1, \mathrm{pH}$ optimal in Experiment 2 for experiments. (4) Determine the maximum adsorption capacity. Based on the results in Experiment 3 to calculate the adsorption capacity from which the maximum adsorption capacity is determined. (5) Determination of $\mathrm{Pb}^{2+}$ concentration $\mathrm{The} \mathrm{Pb}^{2+}$ content was determined by atomic absorption spectrometry on the CONTRAA 700 in the analytical Lab, the Institute of Chemistry and Materials, the Military Science and Technology Institute; Institute of Tropical Technology, Vietnamese Academy of Science and Technology. Construct the $\mathrm{Pb}^{2+}$ concentration gauge linear equation. Prepare a series of 10 pods with $25-\mathrm{ml}$ volumetric, numbered from 0 to 9 and extract the volumes according to Table 3 , set to the mark with distilled water, shake well and measuring the Abs value of the solution at a wavelength $\lambda=283 \mathrm{~nm}$. (6). Test results: Investigation results of $\mathrm{MB}, \mathrm{MO}, \mathrm{Pb}^{2+}$ adsorption in water environment using materials from PY19 sample are shown in the Table 4.

Table 3 Standard table set the $\mathrm{Pb}^{2+}$ level

\begin{tabular}{|c|c|c|c|c|}
\hline$\pi$ & $\begin{array}{c}\text { Extract volume } \\
(\mathrm{ml}) \mathrm{Cl}_{\mathrm{lv}}=10 \mathrm{mg} / \mathrm{l}\end{array}$ & Norm (ml) & $\mathrm{C}(\mathrm{mg} / \mathrm{l})$ & Abs \\
\hline 0 & 0 & 25 & 0 & 0 \\
\hline 1 & 0,5 & 25 & 0,2 & 0,00742 \\
\hline 2 & 1,0 & 25 & 0,4 & 0,01491 \\
\hline 3 & 1,5 & 25 & 0,6 & 0,02044 \\
\hline 4 & 2,0 & 25 & 0,8 & 0,02828 \\
\hline 5 & 2,5 & 25 & 1,0 & 0,03609 \\
\hline 6 & 5,0 & 25 & 2,0 & 0,06938 \\
\hline 7 & 10 & 25 & 4,0 & 0,13589 \\
\hline 8 & 15 & 25 & 6,0 & 0,18533 \\
\hline 9 & 20 & 25 & 8,0 & 0,24184 \\
\hline
\end{tabular}


The determined standard calibration curve is:

$y=0.0304 x+0.004 ; R 2=0.9971$

From the standard construction curve (Fig 5), it is found that in the $\mathrm{MB}$ concentration range of 0 to $8 \mathrm{mg} / \mathrm{l}$, the optical absorption level depends linearly on the $\mathrm{Pb}^{2+}$ concentration according to the Lamber-Beer law. Therefore, when determining the concentration of $\mathrm{Pb}^{2+}$ in the sample we need to set up to this concentration.

c) Calculation method for results

- Calculate the concentration:

$$
\mathrm{C}_{\text {đo }}=\left(\text { Abs-b) } / \mathrm{a} \quad \Rightarrow \quad \mathrm{C}_{\mathrm{m}}=\mathrm{C}_{\text {đo }} * \mathrm{f}\right.
$$

where:

$\mathrm{Cm}: \mathrm{Pb}^{2+}$ concentration in the primary sample

$\mathrm{Cđo}: \mathrm{Pb}^{2+}$ concentration in sample after normalising

f: dilution factor

- Calculate the efficiency and absorption capacity:

$$
H=\frac{\left(\mathrm{C}_{o}-C_{t}\right)}{C_{o}} \times 100 \% \quad \text { and } \quad Q=\frac{\left(\mathrm{C}_{o}-C_{t}\right) \times V}{m}
$$

where:

$\mathrm{H}$ : adsorption efficiency (\%)

Q: Adsorption capacity (mg/g)

$\mathrm{C}_{\mathrm{o}}$ : Initial concentration of adsorbent solution ( $\left.\mathrm{mg} / \mathrm{l}\right)$

$\mathrm{C}_{\mathrm{t}}$ : Solution concentration after adsorption by the material $(\mathrm{mg} / \mathrm{l})$

$\mathrm{V}$ : Volume of adsorption solution (liter)

$\mathrm{m}$ : Sample volume (g).

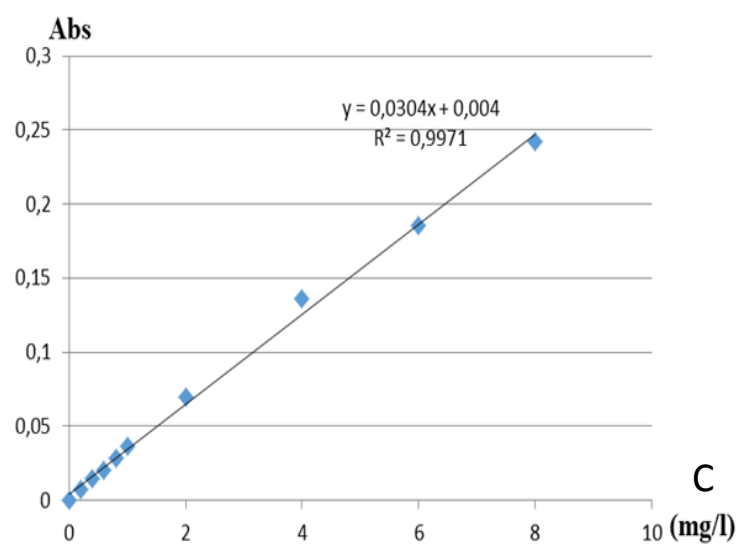

Fig 5 Graph showing the standard deviation of $\mathrm{Pb}^{2}$
Table 4 Adsorption capacity of $\mathrm{MB}, \mathrm{MO}, \mathrm{Pb}^{2+}$ in water environment by PY19 raw material.

\begin{tabular}{|l|l|l|l|}
\hline Absortion Solution & $\mathrm{MB}$ & $\mathrm{MO}$ & $\mathrm{Pb}^{2+}$ \\
\hline Volume (ml) & 50 & 50 & 50 \\
\hline Material quantity (g) & 0,01 & 0,01 & 0,01 \\
\hline Initial concentration (mg/l) & 10 & 10 & 10 \\
\hline Concentration after treatment (mg/l) & 1,755 & 6,057 & 1,316 \\
\hline Eficiency (\%) & 82,45 & 39,43 & 86,84 \\
\hline
\end{tabular}

Table 4 shows that in normal conditions, PY19 material has the ability to adsorb $\mathrm{MB}, \mathrm{MO}$ and $\mathrm{Pb}^{2+}$ in water environment. Specifically, $\mathrm{Pb}^{2+}$ adsorption efficiency was $86.84 \%$; $\mathrm{MB}$ is $82.45 \%$ and $\mathrm{MO}$ is $39.43 \%$. From the above results, the adsorption efficiency of $\mathrm{Pb}^{2+}$ MB of PY19 is higher than MO adsorption, which can be caused by $\mathrm{MB}$ and $\mathrm{Pb}^{2+}$ with positive charge while PY19 material with negative charge so more easy absorption. Therefore, the subject using adsorbent solution is $\mathrm{Pb}^{2+}$ to investigate material PY19.

Table $5 \mathrm{~Pb}^{2+}$ adsorption in water environment by PY19 material at different heating temperatures.

\begin{tabular}{|l|c|c|c|c|}
\hline \multicolumn{1}{|c|}{ Material } & $\begin{array}{c}\text { PY19- } \\
\text { Raw }\end{array}$ & $\begin{array}{c}\text { PY19 } \\
650^{\circ} \mathrm{C}\end{array}$ & $\begin{array}{c}\text { PY19 } \\
750^{\circ} \mathrm{C}\end{array}$ & $\begin{array}{c}\text { PY19 } \\
900^{\circ} \mathrm{C}\end{array}$ \\
\hline $\begin{array}{l}\mathrm{Pb}^{2+} \text { initial } \\
\text { concentration (mg/l) }\end{array}$ & 17,97 & 17,97 & 17,97 & 17,97 \\
\hline $\begin{array}{l}\mathrm{Pb}^{2+} \text { concentration } \\
\text { after treatment (mg/l) }\end{array}$ & 4,342 & 2,438 & 2,17 & 1,743 \\
\hline Hiệu suất (\%) & 75,84 & 86,43 & 87,92 & 90,3 \\
\hline
\end{tabular}

The results shown in Table 5 indicates that the heating material at $900^{\circ} \mathrm{C}$ has the highest adsorption efficiency of $90.3 \%$, so the material is heated at $900^{\circ} \mathrm{C}$ as adsorbent for subsequent experiments.

Investigation of the effect of concentration on $\mathrm{Pb}^{2+}$ adsorption capacity on modified PY19 material Experimental conditions: $\mathrm{Pb}^{2+}$ adsorption with different concentrations of $10,20,50,75,100$, and $200 \mathrm{mg} / 1$ with the quantity of $0.01 \mathrm{~g}$ material at $25^{\circ} \mathrm{C}$, normal light, $\mathrm{pH}$ $=7$ for 2 hours. The results are summarized and presented in Table 6 and Fig 6 
Table 6 The effect of concentration on $\mathrm{Pb}^{2+}$ adsorption capacity on modified PY19 material.

\begin{tabular}{|c|c|c|c|c|c|}
\hline$\pi$ & $\begin{array}{c}\mathrm{C}_{0} \\
(\mathrm{mg} / \mathrm{l})\end{array}$ & $\begin{array}{c}\mathrm{C}_{\mathrm{t}} \\
(\mathrm{mg} / \mathrm{l})\end{array}$ & $\begin{array}{c}\mathrm{Q}_{\mathrm{t}} \\
(\mathrm{mg} / \mathrm{g})\end{array}$ & $\begin{array}{c}\mathrm{C}_{\mathrm{t}} / \mathrm{Q} \\
(\mathrm{g} / \mathrm{l})\end{array}$ & $\begin{array}{c}\text { Adsorption } \\
\text { efficiency (\%) }\end{array}$ \\
\hline 1 & 8,98 & 0,842 & 40,69 & 0,021 & 90,63 \\
\hline 2 & 17,97 & 1,25 & 83,6 & 0,015 & 93,04 \\
\hline 3 & 47,63 & 6,25 & 206,9 & 0,03 & 86,88 \\
\hline 4 & 73,19 & 15,197 & 289,965 & 0,0524 & 79,23 \\
\hline 5 & 95,26 & 24,704 & 352,78 & 0,07 & 74,06 \\
\hline 6 & 182,77 & 76,84 & 529,6 & 0,145 & 57,96 \\
\hline
\end{tabular}

Table 6 indicates that the material adsorbs $\mathrm{Pb}^{2+}$ only at a certain concentration, so the higher the concentration, the adsorption efficiency will be decreased. Specifically, the adsorption level of $\mathrm{Pb}^{2+}$ is best from 8.98 to $47.63 \mathrm{mg} / \mathrm{l}$ with an efficiency of $80 \%$. From 47.63 to $182.77 \mathrm{mg} / \mathrm{l}$, the adsorption capacity is reduced, resulting in a decrease to bellow $80 \%$.

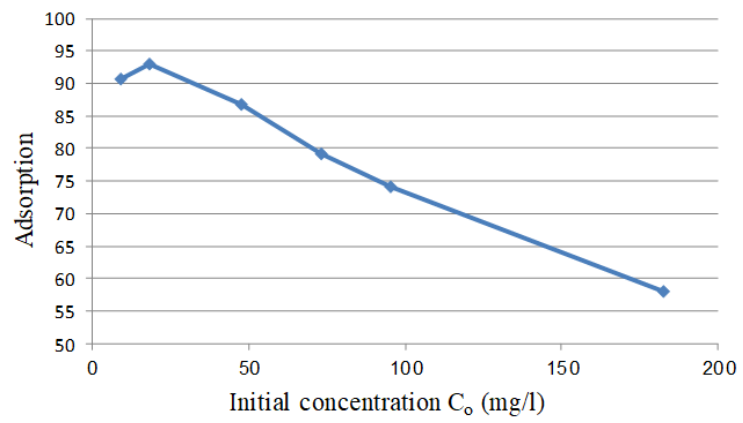

Fig 6 Effect of concentration on $\mathrm{Pb}^{2+}$ adsorption capacity of PY19 material heating at $900^{\circ} \mathrm{C}$

Test to determine the $\mathrm{Pb}^{2+}$ maximum adsorption capacity $\mathrm{Pb}^{2+}$ maximum adsorption capacity was determined by Langmuir adsorption model. Based on the results in Table 6, the graphs are shown in Fig 7 and Fig 8.

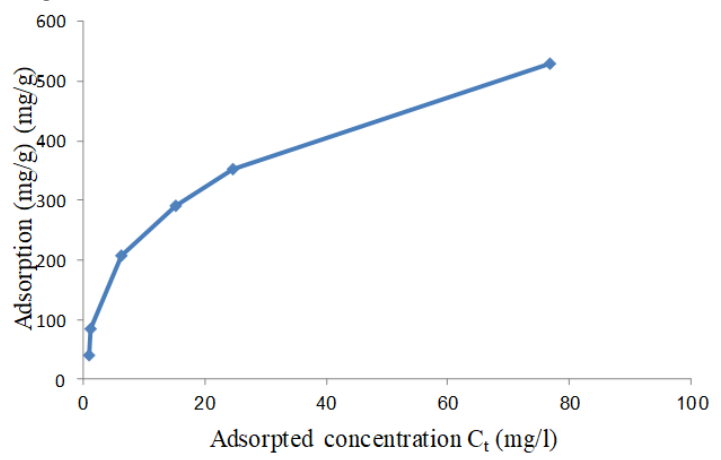

Fig 7 Isothermal Langmuir Line

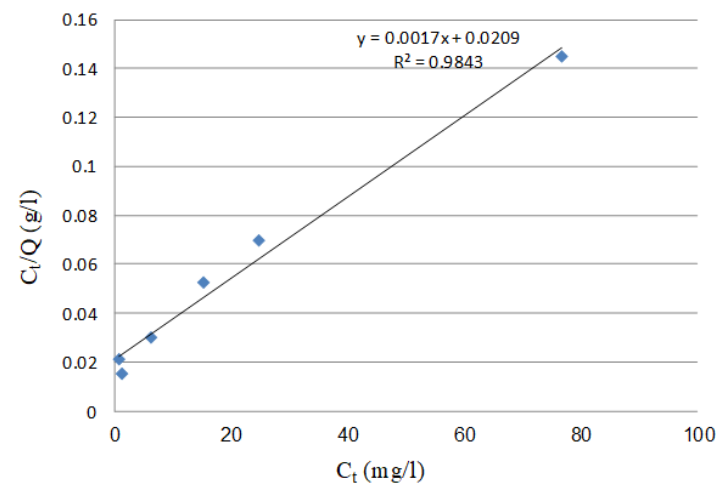

Fig 8 The depending of $\mathrm{Ct} / \mathrm{Q}$ on $\mathrm{C}_{\mathrm{t}}$

From Fig 8, the maximum adsorption capacity of the $\mathrm{Pb}^{2+}$ adsorption material is:

$$
\mathrm{Q}_{\max }=\frac{1}{0,0017}=588,24(\mathrm{mg} / \mathrm{g})
$$

The results showed that with 1 gram of PY19 material can absorb maximum 588.24 $\mathrm{mg} \mathrm{Pb}^{2+}$ in water environment.

In summary: The experiment showed that the PY19 material was modified by calcination and exploring the $\mathrm{Pb}^{2+}$ adsorption capacity in the waste water samples lead to the following results:

- Made of modified PY19 material. The using X-ray diffraction and SEM have proven that the material is crystalline state with the regular distribution of $\mathrm{Si}, \mathrm{O}, \mathrm{Al}$, and $\mathrm{Na}$ elements in each region and closely linked each other to help form strong affinities with capable of adsorbing $\mathrm{Pb}^{2+}$.

- Investigated the $\mathrm{Pb}^{2+}$ adsorption capacity of the modified PY19 material, which showed that the $\mathrm{Pb}^{2+}$ adsorption process was good at 2 hours. The optimum $\mathrm{pH}$ value for adsorption is 7 and the best adsorption range is $8.98-47.63 \mathrm{mg} / \mathrm{l}$. The $\mathrm{Pb}^{2+}$ maximum adsorption capacity is $588.24 \mathrm{mg} / \mathrm{g}$.

\section{CONCLUSION}

The young felsic volcanic rocks and volcanic ashes (Late Mesozoic-Cenozoic ages) are widely distributed in the West and North East of Vietnam as well as in the Central coastal area and Central Highlands. Among them, tuff and basalt ash distributed quite widely in the Central Highlands with high amorphous silica content (glass) which is of great potential for use in the environment. Initial test results from the authors showed that, for lead $\left(\mathrm{Pb}^{2+}\right)$, depending on the concentration of the solution and the environmental conditions $(\mathrm{pH})$, the modified material (heated at $900{ }^{\circ}$ C) can have 
adsorption capacity from $57 \%$ to over $93 \%$ of lead ion in solution. This is only the initial result, but it is also an encouraging premise for further research to comprehensively assess the size and range of these materials and their adsorption capacity for other objects (heavy metals, organic complexes, etc.) in order to assess their applicability in the environment.

\section{ACKNOWLEDGMENTS}

The data published in this paper are taken from the B2016-MDA-16DT project.

\section{REFERENCES}

[1] Le Maitre (Eds), 2002. Igneous rocks: a classification and glossary of terms: recommendations of the International Union of Geological Sciences, Sub Commission on the Systematics of Igneous Rocks. Cambridge University Press. New York, 254 pags.

[2] Uses for Perlite, Hess Perlite, P.O. Box 162, Malad, Idaho. http://www.hessperlite.com/perliteapplications.html

[3] Footler PJ. 2010. Old and new uses for volcanic ash", pharmaceutical-journal.com.

[4] Joan Marti and Gerald Ernst (Eds), 2005. Volcanoes and the Environment. Cambridge University Press, UK. 489 Pags.

[5] Ahmet Sarı, Güngör Şahinoğlu, and Mustafa Tüzen (2012). Antimony(III) Adsorption from Aqueous Solution Using Raw Perlite and Mn-Modified Perlite: Equilibrium, Thermodynamic, and Kinetic Studies/ Industrial \& Engineering Research. American Society Publication.

[6] Kogel J. E, Trivedi N.C, Barker J.M, Krukowski S.T, 2006. Industrial Minerals and Rocks (7th ed.), Society for Mining, Metallurgy, and Exploration, Inc., New York, 685-702.

[7] Le T. D, Van Anh P.T et al, 2008. Evaluating resource, reserve and studying production technology for natural puzelan source in North Central Part to serve construction material industry. Project code: B2006-0222TĐ. Ministry of Education and Training of Vietnam. [8] Nguyen, T.M., Doan, D.H., 2011. Results of initial research on the ability to use weathering basalt weathering in Ly Son and Con Co islands on the production of heavy metal adsorption in the treatment of environmental pollution water field". Journal of Geology, Hanoi, 2011.

[9] Lê T D, 2000. Some ideas on Geological Setting of basaltic formation along Da river, Ta Bu-Pa Vinh segment (Son La Hydropower). Journal of Geology, Series A/261/11-12

[10] Do, D.T., Nguyen, V.C. 1993. Formations of volcanic rocks of Song Hien formation in Binh Gia, Lang Son. Journal of Geology, 216-217, Hanoi.

[11] Phan, T.D, Nguyen, B, Tran, N.T. 1977. The remarks of perlite and opsidien in the volcanics in Binh Lieu, Quang Ninh. Journal of Geology No. 134, Hanoi. Vietnam.

[12] Vu, N.H et al. 1988. Formations of late Mesozoic volcanic formations in Da Lat. Journal of Geology, Hanoi.

[13] Dao, D.T., Huynh, T. 1995. Geology of Vietnam. Episode II. Magma Formations. Department of Geology of Vietnam, Hanoi, 359 pages.

[14] Le, T.D, Pham, T.A.A, et al. 2005. Late Mesozoic volcanic and plutonic formations in Aluoi-Dak Rong band. Journal of Earth Sciences. No. 2 (T.27) / 2005. Pp. 133-141.

[15] Do, D.T., Le, T.D. et al. 2008. Minerals investigation and and minerals mapping in Kon Tum province. Department of Science and Technology of Kon Tum province.

[16] Bui, M.T. et al. 2010. Activities of Magma in Vietnam. National Institute of Geology and Minerals, 369 pages.

[17] Tran, T., Le, T.D. et al. "Geological sheet 1: 200,000 of Kon Tum-Buon Ma Thuat". Geological Archives, Hanoi. 